\title{
Dampak penggunaan gadget terhadap kepribadian anak sekolah dasar: studi kasus pada siswa ' $\mathrm{X}$ ' (The impact of gadget use on the personality of basic school children: case Studies on Students ' $X$ ')
}

Fahrul Hidayat $^{1 *}$, Hernisawati ${ }^{2}$, Aprezo Pardodi Maba ${ }^{3}$

Program Studi Bimbingan dan Konseling Pendidikan Islam, Institut Agama Islam Ma'arif Nahdlatul Ulama Metro Lampung ${ }^{1,2.3}$

fahrulh63@gmail.com

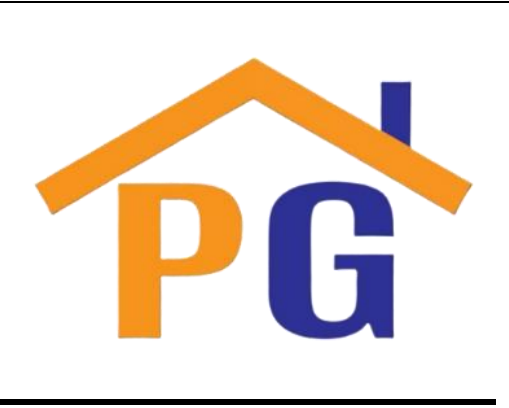

Riwayat Artikel

Diterima pada 12 Maret 2021

Direvisi pada 31 Maret 2021

Disetujui pada 5 April 2021

\begin{abstract}
Purpose: This study aimed to determine the extent of the influence of gadgets on elementary school children, especially in the aspect of personality, as well as how parents' efforts in providing supervision and direction for their children.
\end{abstract}

Research methodology: This type of research is qualitative with the case study method. The instruments used were observation, interviews, and documentation. Meanwhile, for data analysis, researchers used descriptive-analytic techniques. The data analyzed is then tested for validity using the credibility, transferability, dependability, and confirmability tests.

Results: The results of this study indicate that there is an effect of gadgets on children's personalities, including temperament, indifference, a fast-developing mindset without appropriate stages, love to share, and be creative.

Limitations: This research is far from perfect; the author realizes that there are limitations in the research process, one of which is that the subject and object of research are only taken within the scope of the family.

Contribution: This research is expected to be useful in the world of education, especially educators and the family environment as a reference in implementing digital parenting for their children.

Keywords: Gadgets, Personality, Children, Parents

How to cite: Hidayat, F., Hernisawati, \& Maba, A. P. (2021). Dampak penggunaan gadget terhadap kepribadian anak sekolah dasar: studi kasus pada siswa ' $\mathrm{X}$ '. Jurnal Humaniora dan Ilmu Pendidikan, 1(1), 1-13.

\section{Pendahuluan}

Perkembangan zaman saat ini sudahlah sangat pesat dan kompleks. Dimana banyak sekali perubahan diberbagai bidang yang kesemuanya itu memiliki keterkaitan satu sama lain, baik dibidang pendidikan, teknologi, maupun sosial. Namun yang perubahan yang paling signifikan terdapat pada bidang teknologi, karena sekarang ini telah berada dizaman era 4.0 yang bisa dikatakan sebagai era digital atau teknologi. Hampir disetiap bagian kehidupan manusia bergantung pada teknologi. Akibat begitu leluasanya perkembangan dunia teknologi saat ini maka secara langsung maupun tidak langsung telah mengubah gaya hidup manusia yang awalnya masih manual menjadi gaya hidup yang serba digital serta menciptakan kebiasaan-kebiasaan baru. Bahkan bisa dikatakan bahwa kebutuhan akan adanya teknologi merupakan bentuk hipnotis canggih yang mengubah tingkah laku dan cara manusia berkomunikasi (Istiyanto, 2016). Tidak dapat dipungkiri bahwa saat ini banyak dari kalangan anak-anak bahkan usia yang masih sangat muda dibawah 5 tahun sudah pandai mengoperasikan teknologi yang berupa gadget jenis smartphone atau handphone (Tatminingsih, 2017). 
Dalam hal ini penggunaan gadget secara konstan akan berdampak bagi perilaku dan kepribadian anak dalam kesehariannya. Bagi anak-anak yang sering menggunakan gadget ia akan merasa sangat bergantung dan bahkan menjadi kegiatan yang wajib dilakukan dalam kegiatan sehariharinya. Sebab itu saat ini banyak anak-anak yang lebih sering bermain gadget daripada harus belajar atau bersosialisasi dengan lingkungan sekitar (Al-Ayouby, 2017). Kondisi tersebut sangatlah mengkhawatirkan, karena masa anak-anak identik dengan sifat yang belum stabil serta mempunyai rasa keingintahuan yang besar sehingga dapat meningkatnya prilaku konsumtif pada anak. Berdasarkan sifat perkembangan anak tersebut maka timbulah beberapa dampak yang dapat merugikan bagi tumbuh kembang anak, mulai dari kecanduan internet, game, serta konten-konten yang berisi pornografi (Putri, 2018). Kebanyakan anak lebih mementingkan bermain gadget dari pada melakukan rutinitas yang mesti dilakukan setiap hari. Tak jarang juga anak yang mengabaikan perintah orang tua demi fokus pada gadget. Mengkhawatirkannya lagi saat anak sudah fokus dan terlalu asyik dengan gadget yang sudah di tangan, ia tidak akan memperdulikan lagi sekelilingnya, bahkan menengok kanan kiri pun ia tak mau (Al-Ayouby, 2017). Hal ini didukung oleh para orang tua yang menganggap ini biasa-biasa saja dalam bermain gadget, bahkan tak jarang orang tua yang menganjurkan anaknya untuk bermain gadget dengan tujuan agar tidak rewel dan susah diatur (Rahmawati, 2018). Hampir setiap anak saat ini telah menggunakan gadget. Kondisi ini ditandai dengan adanya berita yang mengatakan bahwa Indonesia termasuk salah satu dari 10 negara dengan mempunyai peminat gadget yang sangat tinggi (Supriyadi, 2018). Itulah salah satu bentuk akibat kecanduan anak-anak terhadap gadget yang dimiliki. Untuk itu perlu perhatian khusus serta pengawasan dari orang tua.

Asosiasi Dokter Anak Amerika Serikat dan Canada menekankan bahwa anak dengan usia 0-2 tahun dianjurkan untuk sama sekali jangan terpapar gadget. Sedangkan anak dengan usia 3-5 tahun dibolehkan menggunakan gadget namun dibatasi selama 1 jam/hari dan untuk anak usia 6-18 tahun hanya diperkenankan selama 2 jam/hari. Namun faktanya, mayoritas anak justru menggunakan waktu bermain gadget lebih banyak dibandingkan dengan anjuran tersebut. Bahkan lebih parahnya lagi penggunaan gadget seperti smartphone, tablet, piranti elektronik lainnya telah dipergunakan sejak masih anak usia dini (Kartika, 2014). Pemakaian gadget yang terlalu lama akan berdampak bagi kesehatan anak serta kepribadiannya. Sangat membahayakan jika anak menghabiskan banyak waktu hanya sekedar untuk bermain dengan gadget tanpa berkepentingan. Seringnya penggunaan gadget akan menyebabkan kecanduan bagi anak. Dalam artian anak tersebut tidak akan pernah lepas dari piranti gadget dan akan sulit untuk disembuhkan (Ladika, 2018).

Berdasarkan fakta-fakta diatas kita sebagai makhluk yang berakal tidak bisa membalikkan badan akan hal iti. Kita mengetahui bahwa banyak sekali manfaat yang dapat kita peroleh dari menggunakan gadget namun juga tidak bisa begitu saja melupakan dampak negatif yang dapat dirasakan. Melalui kegiatan obervasi dan pengalaman penulis, telah nampak kejadian yang serupa dengan fakta diatas. Beberapa keluarga/orang tua telah memberikan anaknya sebuah piranti gadget pribadi. Salah satunya yang terjadi dikeluarga Bapak S dan Ibu K, mereka membelikan gedget untuk anaknya yang masih berusia 9 Tahun. Padahal kalau kita cermati anak dibawah umur 9 tahun mayoritas masih belum bisa membedakan dan mencerna baik atau buruknya sesuatu yang ada di hadapannya. Tapi walaupun demikian, jika orang tua memberikan pengawasan dan pendampingan yang optimal bukan tak mungkin gadget tersebut menjadi sebuah alat untuk perkembangan anak. Dari sinilah penulis bermaksud mengangkat sebuah masalah/kasus yang telah terjadi di masyarakat. Penulis tertarik meneliti kasus yang terjadi pada pasangan keluarga Bapak S dan Ibu K mengenai pengaruh penggunaan gadget terhadap kepribadian anaknya yang berinisal X.

\section{Tinjauan pustaka dan pengembangan hipotesis \\ a. Perkembangan anak}

Anak merupakan generasi penerus dimasa depan yang akan menjadi bagian dari masyarakat. Oleh sebab itu, baiknya sejak dini seorang anak telah diajarkan untuk bermasyarakat agar nantinya ia dapat tumbuh dan berkembang menjadi manusia yang dapat menjalankan fungsi-fungsi sosialnya. Orang tua harusnya menyadari bahwa dirinya juga merupakan bagian kecil dari masyarakat, sehingga sejak dini orang tua berkewajiban menyiapkan anaknya untuk bersosialisasi yang didalamnya terjadi proses interaksi satu sama lain. Masa anak merupakan periode perkembangan yang berlangsung cepat dan juga periode 
dimana terjadinya perubahan dalam berbagai aspek, mulai dari aspek psikologi, fisik, akademis, maupun sosial (Basire, 2010).

Hurlock menyebutkan bahwa manusia pada umumnya berkembang melalui beberapa tahapan yang saling berurutan serta terus menerus (Al-Ayouby, 2017). Tahapan-tahapan tersebut dapat dipahami lebih jelas pada uraian berikut:

1) Masa prenatal : Sejak masa konsepsi sampai lahir

2) Masa jabang bayi (infancy): Sejak lahir - 10/14 hari

3) Masa bayi (babyhood) : 2 minggu - 2 tahun

4) Masa anak-anak awal : 2 tahun - 6 tahun

5) Masa anak-anak akhir : 6 tahun- 13/14 tahun

6) Masa remaja : $12 / 13$ tahun-21 tahun

7) Masa dewasa : 21 tahun-40 tahun

8) Masa tengah baya : 40 tahun-60 tahun

9) Masa tua : 60 tahun-meninggal

Berdasarkan usia, anak sekolah dasar (SD) dikategorikan kedalam masa anak-anak akhir (late childhood). Masa ini berlangsung dari usia 6-12 tahun yang umumnya mempunyai kemampuan membaca, menulis, berhitung, dan mengenal budaya (Haryadi \& Irawan I. U., 2016). Di Indonesia rata-rata anak mulai masuk di sekolah dasar saat ia berusia 6 tahun dan diusia 12 tahun. Menurut Havighurts, tugas perkembangan anak sekolah dasar meliputi (Hurlock, 1972):

1) Belajar membaca, menulis, dan berhitung.

2) Mulai menguasai keterampilan fisik yang diperlukan dalam aktivitas.

3) Belajar hidup sehat serta bekerja kelompok dengan teman sebaya.

4) Memahami peranan sosial sesuai dengan jenis kelamin.

5) Membangun sejumlah konsep untuk berpikir efektif.

6) Mengembangkan hati nurani, moralitas dan nilai-nilai.

7) Mencapai kemandirian pribadi.

8) Mengembangkan sikap terhadap komunitas dan intitusi.

9) Mulai belajar memahami tentang masalah perkembangan usia.

\section{b. Gadget (Smartphone)}

Menurut Ensiklopedia, Gadget (Bahasa Indonesia: Gawai) merupakan istilah yang berasal dari Bahasa Inggris yang merujuk pada suatu peranti atau instrumen berukuran kecil yang memiliki fungsi praktis yang spesifik pada setiap perangkatnya dibandingkan dengan teknologi sebelumnya (Ensiklopedia, 2019). Gadget didesain lebih pintar karena memiliki fitur lengkap dibandingkan dengan teknologi normal pada masanya. Dari banyaknya jenis gadget yang diciptakan, handphone adalah salah satu bantuk gadget yang paling banyak digunakan, karena bentuknya yang kecil, praktis dan mudah dibawa kemana-mana (Tatminingsih, 2017).

Pada mulanya, gadget diciptakan untuk memudahkan konsumen dalam menggunakan media komunikasi. Jenis gadget tidak hanya tertuju pada handphone (smartphone) tetapi dalam lingkup yang cukup luas. Hampir setiap perangkat elektronik kecil yang mempunyai fitur khusus serta menyajikan teknologi terbaru bisa tergolong jenis gadget (Ladika, 2018).

Para pakar kesehatan mempunyai sebuah pandangan yang termuat dalam Alodokter.com bahwasanya penggunaan gadget pada anak haruslah dibatasi. Para pakar menyarankan untuk memberi kesempatan pada anak bermain gadget hanya berkisar 1-2 jam per hari, itu pun disesuaikan jenjang umur. Untuk anak dibawah 2 tahun dianjurkan tidak sama sekali terpapar gadget. Kemudian anak dengan usia 2-5 tahun disarankan hanya 1 jam per hari dengan pengawasan. Sedangkan anak sekolah dasar usia 6 tahun keatas maksimal hanya 2 jam per hari atau hanya sekali pemakaian di akhir pekan (misalnya hari minggu). Jadi dapat disimpulkan bahwa, pertama penggunaan gadget dengan intensitas jarang (kategori ideal) maka hanya 1-2 jam per hari bagi anak usia sekolah dasar. Kedua, penggunaan gadget dengan intensitas sering (berlebihan) apabila lebih dari 2 jam perhari (Alodokter, 2018). 


\section{c. Dampak gadget}

Dampak pengaruh Gadget pada perkembangan anak sangat banyak. Dampak yang diberikan terbagi dua yaitu, dampak positif dan dampak negatif.

1) Dampak positif

a) Menambah pengetahuan/wawasan.

b) Mempermudah untuk belajar.

c) Meningkatkan motivasi dan minat belajar anak (Alia, 2018).

d) Melatih kreativitas anak.

e) Memperluas jaringan persahabatan.

f) Mempermudah komunikasi (Rahmawati, 2018).

2) Dampak Negatif

a) Pertumbuhan otak tidak stabil.

b) Penyakit mental.

c) Adiksi (Kecanduan).

d) Gangguan tidur (Hasanah, 2017).

e) Mengganggu kesehatan.

f) Rawan terhadap tindak kejahatan (Rahmawati, 2018).

g) Tumbuh kembang anak terhambat.

h) Prestasi menurun.

\section{d. Kepribadian}

Istilah "kepribadian" mengandung banyak arti, tergantung siapa yang mengartikannya. Banyaknya arti mengenai kepribadian ini disebabkan karena adanya perbedaan dalam penyusunan teori, penelitian, dan pengukurannya. Berikut pengertian kepribadian menurut beberapa ahli terpercaya, diantaranya (Chairilsyah, 2012):

1) George Kelly menerangkan bahwa kerpibadian merupakan cara unik dari setiap individu dalam mewujudkan pengalaman-pengalaman hidupnya.

2) Gordon Allport berpendapat bahwa kepribadan adalah suatu organisir yang dinamis dari sistem psiko-fisik seseorang yang menghasilkan tingkah laku dan pola pikir yang khas disetiap individunya.

3) Sigmund Freud menyimpulkan bahwa kepribadian adalah suatu struktur yang terdiri dari ego, ide dan super ego yang saling berintegritas membentuk suatu wujud kepribadian, seperti sikap, pola pikir, dan tingkah laku.

4) Sedangkan menurut Browner, kepribadian merupakan corak tingkah laku, dorongan atau keinginan, opini dan sikap seseorang. Kepribadian setiap individu ada yang bersifat nampak ada juga yang tidak nampak.

Dari berbagai definisi di atas, maka penulis dapat menyimpulkan bahwa kepribadian merupakan hasil dari pengalaman-pengalaman individu dalam berinteraksi dengan lingkungan yang diwujudkan dalam bentuk tingkah laku, emosi, sikap, pola pikir, norma atau cita-cita, baik yang nampak maupun tidak nampak. Kepribadian terbentuk, dipertahankan, dan berubah jika mengalami proses sosialisasi (pengalaman) yang kuat pada diri seseorang. Secara umum para ahli psikolog berpendapat bahwa kepribadian merupakan suatu mekanisme yang mengendalikan sikap dan prilaku seseorang. Kepribadian terbentuk melalui pengalamanpengalaman dan nilai-nilai yang diserap dalam tumbuh kembangnya, terutama pada tahuntahun pertama umurnya (Basire, 2010). Kepribadian seseorang terdiri dari beberapa aspek, diantaranya yaitu:

1) Aspek kejasmanian, yang berarti wujud sesuatu yang nampak dari luar, misalnya seperti cara berbicara atau tingkah laku.

2) Aspek kejiwaan, sesuatu yang tidak nampak dari luar, seperti cara berpikir, bersikap, serta emosi.

3) Aspek kerohanian, merupakan aspek kejiwaan yang lebih abstrak, misalnya falsafah hidup dan kepercayaan. Aspek ini meliputi nilai atau norma yang telah mendarah daging sehingga membentuk dan mengarahkan corak disetiap kehidupannya (Sukaimi, 2013).

Kepribadian anak tidak terbentuk sekali jadi, melainkan terbentuk secara bertahap berbarengan dengan proses tumbuh kembangnya. Pembentukan kepribadian tidak hanya 
melalui sebuah pelajaran (teori), tetapi juga melalui contoh nyata dari bimbingan orang tua serta guru atau pembimbing (Subqi, 2016). Menurut Freud, kegagalan dalam menanam kepribadian yang baik di usia anak akan membentuk pribadi yang bermasalah dimasa dewasanya kelak. Untuk itu, peran aktif orang tua sangat diperlukan karena menjadi elemen terpenting dalam pembentukan kepribadian atau karakter anak (Prasanti \& Fitriani, 2018). Kepribadian bukanlah sesuatu yang bersifat statis (tidak berubah), melainkan memiliki sifat yang dinamis (dapat berubah) yang terkadang dikenal sebagai dinamika kepribadian (Chairilsyah, 2012).

Para pakar psikolog telah melakukan beberapa penelitian untuk menguak tipe-tipe kepribadian seseorang. Para pakar tersebut akhirnya masing-masing mengemukakan teori mengenai jenis atau isi kepribadian seorang manusia., diantaranya sebagai berikut:

1) Gregory, membagi tipe kepribadian menjadi 12 , yakni : 1) Kepribadian yang mudah menyesuaikan diri; 2) Kepribadian yang berhati-hati; 3) Berambisi; 4) Kepribadian yang mempengaruhi; 5) Kepribadian yang berprestasi; 6) Kepribadian yang idealis; 7) Sabar; 8) Perseptif; 9) Peka; 10) Tegas; 11) Ulet.

2) Immanuel Kant, mengklasifikasikan beberapa tipe mengenai kepribadian, yakni sebagai berikut: 1) Tipe sanguin: memiliki banyak kekuatan, semangat, dan dapat membuat lingkungannya gembira atau senang. 2) Tipe plegmatis: pribadi yang tenang, dapat menguasi dirinya dengan baik, dan mampu melihat permasalahan secara baik dan mendalam. 3) Tipe melankolik: pribadi yang mengedepankan perasaan, peka, sensitif terhadap keadaan dan mudah dikuasai oleh mood. 4) Tipe kolerik: pribadi yang cenderung berorientasi pada tugas, disiplin, setia dan bertanggung jawab. 5) Tipe asertif: pribadi yang mampu menyatakan ide, pendapat, gagasan secara tegas, kritis, tetapi perasaannya halus sehingga tidak menyakiti perasaan orang lain.

3) Cattel, Eysenk, dan Edward, berkesimpulan bahwa kepribadian manusia terdiri dari sifat alami (dari Tuhan) sehingga kepribadian adalah hasil dari dinamika disetiap sifat-sifat yang ada tersebut. Seperti sifat sabar, cerdas, suka berpetualang, taat, suka bergaul, suka menerima pendapat orang lain, keras, pembohong (pendusta), dan sebagainya (Chairilsyah, 2012).

\section{Metode penelitian}

Jenis penelitian ini dapat diklasifikasikan ke dalam penelitian kualitatif dan dikemas dengan metode Case Study "Studi Kasus". Penelitian ini dilakukan dengan detail dan secara intensif. Peneliti mempelajari tentang latar belakang masalah yang ada pada objek secara aktual yang ada pada saat sekarang dan menjelaskan dalam bentuk gejala maupun proses sosial (Prastowo, 2011). Sumber data dikelompokkan menjadi 2 yakni data primer dan data sekunder. Adapun data primer adalah sumber data penelitian yang diperoleh dari objek utama anak $\mathrm{X}$ serta pihak keluarganya, yakni ayah dan ibu dari anak "X", kakaknya, neneknya, serta paman dan bibinya. Alasan penulis hanya mengambil sebagian kecil informannya adalah karena penulis lebih menekankan pada infromasi dari seseorang yang mengetahui atau selalu berkontak langsung dengan anak tersebut. Sedangkan data sekunder merupakan data yang didapat melalui dokumentasi penelitian terhadap segala sesuatu yang berkaitan dengan penelitian, serta data yang didapat dari media elektronik maupun cetak, literatur, skripsi, bukubuku, dan lain-lain. Teknik pengumpulan data menggunakan teknik observasi, wawancara serta dokumentasi. Observasi ditekankan pada dua aspek, yakni lingkungan dan kepribadian. Adapun untuk teknik wawancaranya peneliti menggunakan model wawancara semi-terstruktur, yang artinya pertanyaan-pertanyaan dari peneliti tidak permanen melainkan bersifat kondisional sesuai kondisi saat melakukan wawancara. Namun walau demikian, topik pertanyaan yang diajukan oleh peneliti kepada informan tetap sesuai dengan pokok permasalahan yang ingin digali dan didasarkan pada aspek-aspek tertentu seperti lingkungan dari anak X, pendidikan, pergaulan, pola asuh, kegiatan sehari-hari serta latar belakang dari anak tersebut. Sedangkan untuk teknik analisis data pada penelitian ini menggunakan analitik-deskriptif. Uji keabsahan pada penelitian kualitatif ini meliputi kredibilitas, transferabilitas dan dependabilitas (Sugiyono, 2010). 
4. Hasil dan pembahasan

a. Hasil penelitian

1) Data observasi

Observasi yang dilakukan peneliti mengambil beberapa aspek yakni dari segi lingkungan dan kepribadian dengan beberapa indikator. Data yang diperoleh diuraikan dalam tabel observasi berikut ini:

Tabel 1. Transkip hasil observasi

\begin{tabular}{|c|c|c|c|}
\hline Aspek & Indikator & Data & Sumber \\
\hline \multirow[t]{3}{*}{ Lingkungan } & $\begin{array}{l}\text { Kondisi } \\
\text { keluarga }\end{array}$ & $\begin{array}{l}\text { Orang tua merupakan seorang } \\
\text { petani dan buruh sehingga diwaktu } \\
\text { siang harinya mereka terkadang } \\
\text { tidak melihat secara langsung } \\
\text { aktifitas anaknya setelah sepulang } \\
\text { sekolah. Dan setelah mereka pulang } \\
\text { bekerja pun biasanya mereka } \\
\text { langsung beristirahat. }\end{array}$ & $\begin{array}{l}\text { Keluarga } \\
\text { Bapak "S“" }\end{array}$ \\
\hline & $\begin{array}{l}\text { Intensitas } \\
\text { Penggunaan } \\
\text { Gadget }\end{array}$ & $\begin{array}{l}\text { Setelah beberapa waktu melakukan } \\
\text { observasi dapat diambil kesimpulan } \\
\text { bahwa anak X bermain gadget pada } \\
\text { saat pulang sekolah pukul 12:30 } \\
\text { sampai 14:00 (jarang), waktu sore } \\
\text { setelah pulang mengaji 17-00 } \\
\text { sampai 18:00 (sedang), dan waktu } \\
\text { malam hari 19:00 sampai } 20: 30 \\
\text { (sering). }\end{array}$ & Anak X \\
\hline & $\begin{array}{l}\text { Hubungan } \\
\text { dengan teman } \\
\text { sebaya/Sosial }\end{array}$ & $\begin{array}{l}\text { Hubungan dengan teman sebaya } \\
\text { atau sosial masih tergolong stabil, } \\
\text { artinya walaupun ia sering bermain } \\
\text { gadget namun ia juga masih } \\
\text { menyempatkan untuk bermain } \\
\text { dengan teman sebaya, seperti } \\
\text { bersepeda keliling desa, bermain } \\
\text { bola, memancing, bermain } \\
\text { kelereng, bermain layang-layang } \\
\text { dan sebagainya. Bahkan terkadang } \\
\text { gadget dipakai sebagai media } \\
\text { bermain, seperti game online. }\end{array}$ & Anak X \\
\hline \multirow[t]{2}{*}{ Kepribadian } & Emosi & $\begin{array}{l}\text { Anak X menjadi pemarah ketika ia } \\
\text { diganggu saat bermain gadget. }\end{array}$ & Anak X \\
\hline & Bahasa & $\begin{array}{l}\text { Ketika marah diganggu saat } \\
\text { bermain gadget ia terkadang } \\
\text { spontan mengucapkan kata tidak } \\
\text { sopan dan bahkan memostingkan } \\
\text { perkataan tidak sopan ataupun } \\
\text { perkataan orang dewasa dimedia } \\
\text { sosial }\end{array}$ & Anak X \\
\hline
\end{tabular}




\begin{tabular}{|c|c|c|}
\hline Prilaku & $\begin{array}{l}\text { Ia juga terkadang menjadi pribadi } \\
\text { yang acuh terhadap kondisi } \\
\text { disekitarnya, semisal ketika peneliti } \\
\text { atau orang lain memanggilnya } \\
\text { (diajak berbicara) ia sering tidak } \\
\text { menanggapinya. Namun disamping } \\
\text { itu dengan bermain gadget anak } \\
\text { secara tidak langsung belajar } \\
\text { berbagi (dermawan), saat bermain } \\
\text { game online bersama teman } \\
\text { sebayanya ia selalu menawarkan } \\
\text { temannya untuk bergantian. }\end{array}$ & Anak X \\
\hline Pola Pikir & $\begin{array}{l}\text { Dari segi pola pikir terdapat } 2 \text { hal } \\
\text { yang dipengaruhi gadget. Pertama } \\
\text { melatih berpikir kreatif saat } \\
\text { bermain game online. Kedua pola } \\
\text { pikir yang berkembang pesat tanpa } \\
\text { disertai tahapan yang sesuai, artinya } \\
\text { pada usia anak umur } 9 \text { tahun } \\
\text { stimulus untuk pola berpikirnya } \\
\text { seharusnya disesuaikan dengan } \\
\text { tahap-tahap perkembangan. Namun } \\
\text { dengan adanya gadget tersebut, } \\
\text { dunia anak seakan-akan berubah } \\
\text { menjadi dunia remaja. Mengapa } \\
\text { dapat disimpulkan demikian, } \\
\text { karena peneliti juga mengamati } \\
\text { gerak-gerik anak tersebut melalui } \\
\text { aplikasi sosial media (whatsaap), } \\
\text { yang dalam aplikasi tersebut } \\
\text { terlihat bahwa dalam akses sosial } \\
\text { medianya khususnya fitur } \\
\text { "tampilan status" ia sering } \\
\text { menggunakan simbol-simbol } \\
\text { seorang remaja, mulai dari video } \\
\text { percintaan, galau, video atau } \\
\text { gambar pembullyan, "status" kata- } \\
\text { kata jorok, dan lain sebagainya. }\end{array}$ & Anak X \\
\hline Nilai/Norma & $\begin{array}{l}\text { Tidak terlihat nilai-nilai apa yang } \\
\text { tercipta pada diri anak X. Hanya } \\
\text { keinginan dan kepuasan saja yang } \\
\text { ada. }\end{array}$ & Anak X \\
\hline
\end{tabular}

\section{2) Data wawancara}

a) Gadget

Menurut pengakuan dari orang tua asal muasal X mempunyai gadget pribadi terjadi saat anak meminta dikhitan (Jawa: Sunat). Pada saat itu pada bulan Juni 2019 orang tua menawarkan anak X untuk memilih, setelah dikhitan ia ingin diadakan pesta (hajatan) atau dibelikan smartphone (gadget). Hingga akhirnya anak tersebut memilih dibelikan smartphone saja. Seperti yang diungkapkan oleh orang tua anak yakni Bapak S dan Ibu K :

"Ya saat itu anak meminta ingin dikhitan, sedangkan kami belum ada biaya untuk mengadakan pesta (hajatan). Dan saat itu juga anak bersedia tidak diadakan pesta, namun ia ingin dibelikan smartphone saja, gitu”. 
Orang tua menganggap bahwa smartphone (gadget) hanya sebatas alat berkomunikasi serta bermain game. Hal ini mengacu pada pengetahuan orang tua yang minim dalam pengoperasian gadget. Kondisi tersebut mengakibatkan orang tua sangat kesulitan dalam mengawasi penggunaan gadget $\mathrm{X}$. Peran orang tua hanya sebagai pengingat, saat $X$ sudah terlalu lama bermain maka orang tua akan memperingatinya. Intensitas $\mathrm{X}$ dalam bermain gadget berkisar 1 jam bahkan terkadang lebih dari itu. Waktu yang dipakai anak untuk bermain gadget pun biasanya setelah pulang sekolah, sore hari, dan malam hari. Seperti yang diungkapkan Ibu K dan Ibu N (nenek anak X) :

"Biasanya sih ia bermain gadget setelah pulang sekolah dari jam setengah 12 sampai jam 1 an. Terus juga sore hari setelah pulang mengaji jam 5 sore sampai maghrib, juga pada malam hari setelah sholat maghrib hingga menjelang tidur".

Lain halnya bagi saudara I (kakak kandung X), ia sangat tahu betul fungsi dari gadget karena ia juga sudah memilikinya. Bahkan saudara I mengetahui apa saja aktivitas X dalam bermain gadget. Ia menjelaskan kalau adiknya (anak X) tersebut menggunakan gadget hanya untuk bermain game seperti freefire dan pubg, menonton video di youtube, dan terkadang menggunakan sosial media seperti whatsapp dan facebook. Seperti dalam keterangan wawancara dengan saudara "I" yang mengatakan:

"Ya mungkin cuma main game saja atau membuka youtube nonton-nonton video, tapi ia juga mempunyai akun sosial media seperti whatsapp dan facebook. Jadi terkadang ia juga membuka sosial media itu”.

b) Pengasuhan keluarga

Setiap keluarga pasti mempunyai pola asuh yang berbeda-beda untuk anaknya. Pola asuh sendiri merupakan salah satu wujud kasih sayang dan kepedulian orang tua terhadap buah hatinya. Berbagai macam pola asuh orang tua terhadap anaknya bisa berbentuk otoriter (suatu keharusan mutlak bagi anak), permisif (sikap acuh terhadap anak), atau bahkan demokratis (terbuka antara orang tua dan anak). Sebagai contoh yakni yang terjadi pada keluarga Bapak "S". Beliau dan istrinya mempunyai dua orang anak laki-laki. Dalam suatu kesempatan keluarga Bapak S ditanya tentang masalah bagaimana cara mereka mengasuh anak-anak terkhusus anak X. Pada kesempatan tersebut Ibu K menjelaskan secara ringkas :

"Ya biasa saja sih, kami mengasuh anak sewajarnya saja. Saat anak ingin bermain keluar kami perbolehkan, namun dengan catatan ketika anak bermain yang bisa membahakan maka kami melarang, seperti mandi di sungai dan bersepeda jauh. Kami juga selalu mengingatkan anak dengan kewajibannya seperti mengaji, sekolah, belajar, tidak tidur larut malam, serta terlalu lama bermain, kurang lebih begitu".

Keluarga Bapak S tidak memanjakan anak-anaknya, hal ini didasarkan pada kebutuhan ekonomi mereka.

"Kami hanya menuruti ketika keinginan itu baik untuk anak dan melihat kemampuan kami dalam segi ekonomi”. Ucap Bapak S

Hal ini dapat dicerminkan pada sikap keluarga terhadap anak X dalam penggunaan gadget, dimana keluarga tidak selalu membelikan pulsa atau data bagi anak. Seperti yang diucapkan oleh Ibu K:

"Kami hanya membelikan pulsa atau data kalau ada rejeki saja".

c) Pemanfaatan gadget

Umumnya gadget diciptakan untuk hal-hal positif yang mempermudah kehidupan manusia. Namun kenyataannya gadget sampai saat ini tidak hanya berdampak positif melainkan ada juga dampak negatifnya. Sebagai contoh pada pasangan keluarga Bapak S dan Ibu K, mereka awalnya membelikan gadget anaknya supaya ia semangat belajar serta mempermudah berkomunikasi namun kenyataannya malah sebaliknya. Seperti yang dikatakan oleh Ibu N (Nenek) :

" $X$ susah diatur sekarang, kalau disuruh belajar pasti nggak mau, ia mau belajar kalau ada PR saja". 
Ditegaskan pula oleh Ibu K bahwa prestasi anaknya sekarang menurun semenjak memiliki gadget. Dari awalnya X mendapat peringkat 3 di kelas III sekolah dasar sekarang ia tidak mendapat peringkat setelah mempunyai gadget. Kondisi ini sangat mengkhawatirkan jika dibiarkan terus menerus. Sebenarnya keluarga Bapak S telah berupaya menasihati bahkan sampai memarahi anaknya jika bermain gadget secara berlebihan. Namun upaya tersebut rupanya belum terealisasikan bagi anaknya, ia selalu saja bermain gadget sepanjang waktu hingga lupa dengan tugasnya sebagai anak-anak.

Dampak negatif yang terjadi pada $\mathrm{X}$ bukan hanya sebatas pada prestasinya saja. Melainkan juga pada aspek-aspek kepribadiannya, seperti sikap, prilaku, bahasa dan pola pikir anak. Dalam kesempatan wawancara, ditemukan beberapa data mengenai perubahan kepribadian anak X sebelum dan sesudah mempunyai gadget. Bapak S yang merupakan ayah kandung dari anak tersebut menjelaskan bahwa semenjak mempunyai gadget pribadi sekarang anaknya terkadang menjadi pribadi susah diatur yang tidak memperhatikan nasihat dari orang tua maupun keluarga lainnya, seperti nasihat untuk berhenti bermain gadget. Tetapi ketika nasihat orang tua tersebut disertai dengan hukuman semisal gadget akan diancam dijual atau dengan peringatan fisik (jewer, dan lain-lain yang bersifat mendidik) maka seringkali anak langsung patuh tehadap orang tua maupun keluarganya.

Selain itu prilaku yang telah dijelaskan diatas, ternyata masih ada perubahan lain. Diantaranya yang dijelaskan oleh keluarga Bapak G selaku pamannya X:

" $X$ kadang kalo pas diganggu bermain gagdet biasanya ia marah-marah setelah itu mengeluarkan kata jorok".

Keluarga pamannya pun bahkan sampai terheran-heran, bagaimana mungkin anak yang masih umur 9 tahun sudah pintar bermain gadget yang notabennya banyak sekali fitur yang rumit. Ini menunjukkan bahwa seseorang bahkan masih anak-anak setelah menggunakan gadget pertumbuhan otak (daya pikir) berkembang cepat sekali. Perkembangan ini bukanlah suatu hal yang positif, melainkan merujuk pada hal yang negatif karena proses perkembangan otak tidak berjalan beriringan dengan tugas-tugas pada fase anak usia tersebut.

Akan tetapi walaupun banyak sekali dampak negatifnya ternyata masih menyisakan hal yang positif yakni dengan bermain gadget anak belajar berbagi seperti bermain bersama teman sebaya dan bergantian untuk bermain game. Bahkan sering kali masih ada waktu-waktu luang yang dipakai $\mathrm{X}$ untuk bermain dengan temannya di luar rumah tanpa gadget.

\section{b. Pembahasan}

Gadget merupakan wujud dari perkembangan teknologi saat ini, bahkan uniknya gadget dijadikan sebagai keharusan yang harus dimiliki oleh setiap individu mulai dari anak-anak sampai dewasa. Gadget sejatinya mempunyai ruang lingkup yang cukup luas artinya gadget merupakan suatu istilah untuk mengelompokkan macam-macam teknologi mini yang mempunyai multifungsi, seperti smartphone, handphone, i-pad, netbook, blackberry, dan lainlain. Gadget umumnya diciptakan untuk memudah aktivitas manusia yang berarti dalam hal-hal yang positif. Tapi faktanya gadget bukan hanya berdampak pada hal positif namun juga menimbulkan berbagai hal negatif bagi orang yang tidak bisa mengoptimalkan penggunaan gadget. Jenis gadget yang sudah menjadi seperti makanan sehari-hari setiap kalangan baik di perkotaan-pedesaan, miskin-kaya, tua-muda adalah gadget berjenis smartphone.

Berdasarkan rumusan-rumusan masalah yang telah dibuat pada sub bab sebelumnya serta mengacu dari proses observasi, wawancara sekaligus dokumentasi ditemukan bahwa dampak gadget tehadap kepribadian anak sekolah dasar sangatlah besar dan beraneka macam. Walaupun pada penelitian ini hanya merujuk pada satu keluarga namun rumusan masalah ini bersifat umum atau global. Artinya dengan rumusan masalah yang hanya melibatkan satu keluarga saja sudah bisa mewakili keluarga dalam lingkup luas. Hasil penelitian ini menunjukkan bahwa dampak gadget yang berjenis smartphone bagi seseorang khususnya anak 
sekolah dasar sangat bermacam-macam. Dampak penggunaannya pun ada yang positif dan negatif, tergantung bagaimana ia menggunakannya. Dalam penelitian ini diketahui bahwa anak sekolah dasar harusnya belum dianjurkan menggunakan gadget.

Anak usia sekolah dasar yang berusia 6-12 tahun sejatinya belum memiliki jiwa yang stabil. Itu artinya anak belum bisa memilah-milih mana yang baik dan mana yang buruk bagi dirinya. Dilihat pada objek utama pada penelitian ini menunjukkan bahwa anak tersebut belum memfilter dengan baik apa yang ia terima. Terbukti ia menggunakan gadget hanya untuk kesenangannya saja, seperti bermain game, menonton video diyoutube dan sosial media. Bahkan intensitas penggunaan gadget anak tersebut melebihi batas wajar yakni sehari 3 kali dengan durasi 1 jam bahkan lebih dalam sekali pemakaian. Hal ini sudah berlangsung selama kurang lebih setengah tahun dan sampai saat ini sudah terlihat sekali dampak yang ditimbulkan.

Memang sudah sewajarnya anak dikenalkan dengan teknologi (gadget) yang ada sekarang agar anak tidak ketinggalan perkembangan zaman. Namun tentunya hal tersebut tidak terlalu berlebihan dalam mengenalkannya. Hal ini sangat tidak baik bagi tumbuh kembang anak, jika anak berlebihan dengan gadget bahkan sampai kecanduan, maka anak akan sulit diatasi karena ia sudah menganggap bahwa gadget lebih dari sekedar teman (Mustikawati, 2018). Pada orang dewasa, umumnya waktu yang dihabiskan untuk menggunakan gadget berkisar 1-4 jam dalam sekali pemakaian serta dalam sehari dapat memakai gadget berkali-kali. Kondisi ini tidak sewajarnya disamakan dengan usia anak-anak, penggunaan gadget pada anakanak harus dibedakan atau diminimalisir dibandingkan dengan orang dewasa. Karena jika hal ini disamakan maka bukan tak mungkin akan menimbulkan dampak negatif bagi anak, salah satunya rasa kecanduan terhadap gadget akan cepat dirasakan (Nugraheni, 2018).

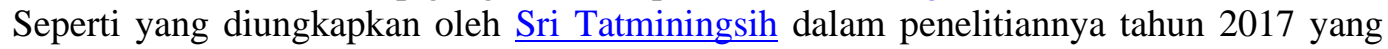
berjudul "Dampak Penggunaan TIK terhadap Prilaku Anak Usia Dini: Studi Kasus pada Anak Usia 4-7 Tahun". Dalam penelitiannya diketahui bahwa intensitas penggunaan Teknologi Informasi dan Komunikasi khususnya gadget bagi anak adalah 5-6 jam perhari. Waktu tersebut lebih lama dibandingkan waktu untuk belajar dan bahkan hampir sama dengan waktu tidurnya. Selain itu penggunaan gadget dapat berdampak positif dan negatif yang dapat berlangsung dalam jangka pendek maupun jangka panjang (Tatminingsih, 2017).

Dari sekian dampak, dampak negatiflah yang paling banyak, diantaranya ; (1) anak sering mengabaikan perintah orang tua, (2) waktu belajar terganggu/prestasi menurun, (3) tempramental, (4) bahasa anak melebihi sistem bahasa pada fase anak umumnya, (5) perkembangan otak anak terlalu cepat tanpa melalui step by step, (6) kecanduan/adiksi, (7) gangguan kesehatan. Namun ternyata masih menyisakan dampak positif bagi anak, seperti ; (1) melatih kreatifitas, (2) belajar berbagi, dan (3) media sosialisasi. Dampak yang telah disebutkan tersebut merupakan dampak secara keseluruhan, namun jika mengacu pada variabel dalam penelitian ini yakni tentang kepribadian anak maka dapat diklasifikasikan sebagai berikut; (1) gampang tempramental, (2) acuh, (3) pola pikir yang berkembang pesat tanpa disertai tahapan yang sesuai, (4) suka berbagi, (5) kreatif.

Melihat dampak-dampak tersebut jika penggunaan gadget berlangsung secara terus menerus tanpa pengawasan, maka bukan tidak mungkin akan timbul banyak lagi dampak negatifnya bagi anak. Untuk itu peran keluarga dibutuhkan untuk mengawasi, membimbing serta memperingatkan anak dalam penggunaan gadet. Bercermin dari objek keluarga dari penelitian ini, dapat disimpulkan bahwa meraka belum ada aturan dan konsistensi dalam mengasuh anak. Artinya peran keluarga bukan hanya melalui lisan saja tetapi juga disertai dengan tindakan. Contoh umumnya, jika anak diperingatkan untuk berhenti bermain gadget tetapi anak mengabaikan maka hal ini perlu adanya tindakan keluarga seperti menyita sementara gadget dari tangan anak. Contoh lain, saat anak diperintah untuk belajar maka orang tua juga harus turut mendampingi anak dalam proses belajar serta membimbing anak menggunakan gadget sebagai media belajar.

Perlu kita ketahui bahwa, sebetulnya segala jenis bentuk dampak penggunaaan gadget terhadap anak itu tergantung pada pengawasan orang tua. Seperti halnya dijelaskan oleh Denak Sintia Rahmawati tahun 2018 dalam penelitiannya yang berjudul "Analisis Penggunaan Gadget terhadap Akhlak Anak (Studi Kasus di SD N 01 Kebonharjo, Klaten)”, yang menyatakan bahwa gadget memiliki dampak besar bagi tumbuh kembang anak terlebih dalam pembentukan 
kepribadian anak. Berdampak positif jika orang tua selalu mengawasi penggunaan gadget pada anak serta mengajarkanya dalam hal positif. Namun juga berdampak negatif jika orang tua memberikan fasilitas gadget pada anak tanpa pengawasan. Dampak positif diantaranya meningkatkan kemampuan bahasa, mengikuti perkembangan teknologi, menghilangkan rasa jenuh belajar, dan internet pendukung akademis. Sedangkan negatifnya yakni kesehatan, kecanduan, sosialisasi berkurang, daya pikir lemah, serta anak jadi pemalas (Rahmawati, 2018).

Pada objek utama penelitian ini sebenarnya anak belum kecanduan secara berlebihan. Anak masih dapat dicegah dengan aturan-aturan dan kebiasaan dari keluarga yang disepakati bersama. Oleh karena itu orang tua harus menerapkan pola digital parenting bagi anakanaknya. Dalam penelitian ini penulis menyarankan beberapa alternatif yang dapat dipakai setiap keluarga umumnya yang mempunyai masalah sama untuk mencegah terjadinya kecanduan gadget pada anak, diantaranya sebagai berikut ; (1) membuat peraturan bersama kapan dan berapa lama anak boleh menggunakan gadget, (2) keluarga harus mengawasi secara aktif, sehingga anak pun akan meminta izin pada keluarga jika hendak menggunakannya, (3) adanya konsistensi dalam menegakkan kebiasaan atau aturan, (4) keluarga harus mendampingi anak saat menggunakan gadget serta membiming anak dalam mengoperasikan gadget dalam hal positif, seperti media belajar, (5) peringatkan anak jika sudah terlalu lama bermain gadget, (6) gadget sebaiknya disimpan oleh orang tua, jangan diserahkan secara penuh kepada anak, (7) berikan hukuman yang bersifat mendidik terhadap anak jika anak mengabaikan perintah keluarga. Peran keluarga bukan hanya pembimbing dan pengingat saja tetapi juga keluarga harus berperan aktif membantu anak dalam proses berkembangnya. Menindak lanjuti kondisi tersebut maka digital parenting perlu dilakukan oleh orang tua, diantaranya sebagai berikut (Primasari dkk., 2019):

1) Memberikan pemahaman tentang dunia internet dan gadget.

2) Pantau aktivitas internet anak melalui aplikasi penyadap khusus atau mengecek secara rutin riwayat browser setiap harinya.

3) Batasi waktu penggunaan gadget pada anak.

4) Berikan peraturan secara tegas apa saja yang tidak boleh diakses dalam gadget pada anak.

5) Menjalin komunikasi yang terbuka dua arah dengan anak.

\section{Kesimpulan}

Setelah melakukan pencarian data dan proses analisis dari penelitian yang berjudul "Dampak Penggunaan Gadget Tehadap Kepribadian Anak Sekolah Dasar (Studi Kasus pada Siswa X)”, maka dapat diambil beberapa kesimpulan guna menjawab beberapa rumusan masalah di atas, yakni sebagai berikut: Dampak negatif keseluruhan ; anak sering mengabaikan perintah orang tua, waktu belajar terganggu/prestasi menurun, tempramental, bahasa anak melebihi sistem bahasa pada fase anak umumnya, perkembangan otak anak terlalu cepat tanpa melalui step by step, kecanduan/adiksi, gangguan kesehatan. Dampak positif keseluruhan, seperti ; melatih kreatifitas, belajar berbagi, dan media sosialisasi. Sedangkan untuk dampak gadget terhadap kepribadian anak sekolah dasar dapat diklasifikasikan sebagai berikut; tempramental, acuh, pola pikir yang berkembang pesat tanpa disertai tahapan yang sesuai, suka berbagi, kreatif. Peran keluarga bukan hanya pembimbing dan pengingat saja tetapi juga keluarga harus berperan aktif membantu anak dalam proses berkembangnya.

\section{Limitasi dan studi lanjutan}

Penulis menyadari bahwa penelitian ini jauh dari kata sempurna, karena keterbatasan penulis dalam memilih subjek penelitian. Oleh karena itu diharapkan bagi para peneliti maupun akademisi dapat melanjutkan penelitian ini dengan menggunakan subjek yang lebih banyak serta teori dan metode yang lebih baik. 


\section{Ucapan terima kasih}

Ucapan terimakasih yang paling utama adalah kepada Tuhan Yang Maha Esa, karena atas nikmat dan karunia Nya, penulis dapat menyelesaikan penelitian ini. Serta para keluarga, kerabat, maupun sahabat yang telah mendukung dalam proses penelitian. Dan yang terakhir terimakasih ditujukan pada keluarga Bapak S dan Ibu K, karena penulis telah diizinkan untuk melakukan penelitian di dalam keluarganya.

\section{Referensi}

Al-Ayouby, M. H. (2017). Dampak Penggunaan Gadget pada Anak Usia Dini (Studi di PAUD dan TK. Handayani Bandar Lampung) [Skripsi]. Universitas Lampung.

Alia, T. (2018). Pendampingan Orang Tua pada Anak Usia Dini dalam enggunaan Teknologi Digital. Polyglot, 14(1).

Alodokter. (2018, Juli 6). Berapa Jam Waktu ideal Anak Gunakan Gadget Setiap Hari? Alodokter. https://www.alodoker.com/berapa-jam-waktu-ideal-anak-gunakan-gadget-setiap-hari

Basire, J. Hi. T. (2010). Urgensi Pendidikan Agama dalam Keluarga terhadap Pembentukan Kepribadian Anak. Jurnal Hunafa, 7(2).

Chairilsyah, D. (2012). Pembentukan Kepribadian Positif Anak Sejak Usia Dini. Educhild, 1(1).

Ensiklopedia. (2019, Oktober 18). Gawai. Wikipedia. https://id.m.wikipedia.org/wiki/Gawai

Haryadi, T., \& Irawan I. U., D. (2016). Penanaman Nilai dan Moral pada Anak Sekolah Dasar dengan Pendekatan Storytelling melalui Media Komunikasi Visual. Andharupa, 2(1).

Hasanah, M. (2017). Pengaruh Gadget terhadap Kesehatan Mental Anak. Indonesian Journal of Islamic Early Childhood Education, 2(2).

Hurlock, E. B. (1972). Child Development (5th ed). McGraw-Hill.

Istiyanto, S. B. (2016). Telepon Genggam dan Perubahan Sosial: Studi Kasus Dampak Negatif Media Komunikasi dan Informasi Bagi Anak-Anak di Kelurahan Bobosan Purwokerto Kabupaten Banyumas. Jurnal Komunikasi Ikatan Sarjana Komunikasi Indonesia, 1(1).

Kartika, U. (2014, Mei 12). 10 Alasan Anak Perlu Lepas dari "Gadget." Kompas.com. https://amp.kompas.com/lifestyle/read/2014/05/12/1640161/10.Alasan.Anak.Perlu.Lepas.dari. Gadget

Ladika, K. N. (2018). Penggunaan Gadget pada Anak Usia Pendidikan Dasar dalam Meningkatkan Interaksi Sosial (Studi Kasus di SDN 1 Karangan Balong Ponorogo). Institut Agama Islam Negeri Ponorogo.

Mustikawati, I. (2018). Pembatasan Penggunaan Gadget pada Anak/Siswa Pendidikan Dasar (Pendidikan 9 Tahun). Majalah Ilmiah "Pelita Ilmu," 1(2).

Nugraheni, A. D. (2018). Pengaruh Gadget terhadap Perkembangan Bahasa Anak Usia Dini. Prosiding Seminar Nasional.

Prasanti, D., \& Fitriani, D. R. (2018). Pembentukan Karakter Anak Usia Dini: Keluarga, Sekolah, dan Komunitas? (Studi Kualitatif tentang Pembentukan Karakter Anak Usia Dini melalui Keluarga, Sekolah, dan Komunitas). Jurnal Obsesi, 2(1).

Prastowo, A. (2011). Memahami Metode-Metode Penelitian: Suatu Tinjauan Teoritis dan Praktis. Ar Ruzz Media.

Primasari, D. A. G., Dencik, \& Imansyah, M. (2019). Pendidikan Karakter bagi Generasi Masa Kini. Prosiding Seminar NasionalPendidikan Program Pascasarjana Universitas PGRI Palembang.

Putri, R. A. (2018). Dampak Penggunaan Smartphone terhadap Perkembangan Prestasi Motorik dan Emosional Siswa Kelas 5 Sekolah Dasar di Air Teluk Kiri Kecamatan Teluk Dalam Kab. Asahan. Medan : Repositori Institusi USU, Univsersitas Sumatera Utara.

Rahmawati, D. S. (2018). Analisis Penggunaan Gadget terhadap Akhlak Anak (Studi Kasus di SD N 01 Kebonharjo, Klaten) [Skripsi]. Universitas Islam Indonesia.

Subqi, I. (2016). Pola Komunikasi Keagamaan dalam Membentuk Kepribadian Anak. Inject (Interdisciplinary Journal of Communication), 1(2).

Sugiyono. (2010). Metode Penelitian Pendidikan: Pendekatan Kuantitatif, Kualitatif, dan R\&D. Alfabeta. 
Sukaimi, S. (2013). Peran Orang Tua dalam Pembentukan Kepibadian Anak: Tinjauan Psikologi Perkembangan Islam. Marwah, 7(1).

Supriyadi, E. (2018, Januari 31). Daftar 6 Negara Pengguna Ponsel Terbanyak di Dunia, Ada Indonesia! IDN Times. https://www.idntimes.com/tech/gadget/eka-supriyadi/daftar-6-negarapengguna-ponsel-terbanyak-di-dunia-ada-indonesia-c1c2

Tatminingsih, S. (2017). Dampak Penggunaan TIK terhadap Perilaku Anak Usia Dini: Studi Kasus pada Anak Usia 4-7 Tahun. Jurnal Pendidikan, 18(1). 